\title{
A rarely encountered case: A neuroendocrine tumor in strangulated Littre's hernia
}

\author{
다) Ahmet Erdoğan, M.D., ${ }^{1}$ 당 Akın Bostanoğlu, M.D. ${ }^{2}$ \\ ${ }^{1}$ Department of General Surgery, Kahramanmaraş Elbistan State Hospital, Kahramanmaraş-Turkey \\ ${ }^{2}$ Department of General Surgery, Ankara Numune Training and Research Hospital, Ankara-Turkey
}

\begin{abstract}
Littre's hernia is a rare condition that involves Meckel's diverticulum in the hernia sac. Meckel's diverticulum is the true diverticulum of the small intestine. Neuroendocrine tumors may develop in it; however, there are very few reported cases. In this study, we present a case of neuroendocrine tumor in strangulated Littre's hernia, on which we did not find a study when we reviewed the relevant literature. A 7I-year-old male patient presented to our outpatient clinic with complaints of left groin pain and swelling in the groin. Acute abdomen findings were also present in the abdominal examination of the patient. The patient was operated on immediately and it was observed during the operation that the herniated Meckel's diverticulum was perforated. Segmental small intestine resection was performed. The pathology results of the patient revealed a well-differentiated neuroendocrine tumor with mucosal and submucosal localization in Meckel's diverticulum. We believe that if Meckel's diverticulum is found in the hernia sac in incarcerated hernias, it must be completely resected as a neuroendocrine tumor may develop, even if only rarely.
\end{abstract}

Keywords: Littre's hernia; Meckel's diverticulum; neuroendocrine tumor.

\section{INTRODUCTION}

Littre's hernia is a rare condition that involves Meckel's diverticulum (MD) in the hernia sac, which was first described by the French surgeon Alexis de Littre in $1700 .^{\left[{ }^{[l]}\right.} \mathrm{MD}$ is the true diverticulum of the small intestine that is formed as a result of the incomplete obliteration of the omphalomesenteric (vitelline) duct, and it occurs in approximately $1 \%$ to $3 \%$ of people. ${ }^{[2]}$ Approximately $4 \%$ of the cases may develop complications requiring surgical or medical treatment, which include gastrointestinal bleeding and obstruction, diverticulitis, and perforation. Benign and malignant tumors can also be observed due to the presence of heterotopic mucosa in the diverticulum ${ }^{[3]}$ In the literature, there are a limited number of cases of neuroendocrine tumors (NETs) in MD. We present a case of a NET in strangulated Littre's hernia. To our knowledge, this is the first case of a NET in strangulated Littre's hernia in the literature.

\section{CASE REPORT}

A 7I-year-old male patient presented to our outpatient clinic with complaints of left groin pain and swelling in the groin. It was found that the patient was experiencing groin pain for two days and had no gas or stool output for 24 hours. As a result of physical examination, it was revealed that the patient had a left incarcerated inguinal hernia. Abdominal examination revealed rebound, defense, and distension. The patient's medical history revealed that he was recently diagnosed with pneumonia and his treatment was ongoing. Blood tests revealed leukocytosis in the hemogram [white blood cell count: $11.9 \times 10^{3} / \mu \mathrm{L}$ (reference range: $4.8-10.8$ )]. Biochemical values revealed that urea and creatinine levels were high [urea: 125 $\mathrm{mg} / \mathrm{dL}$ (17-43), creatinine: $2.01 \mathrm{mg} / \mathrm{dL}(0.8 \mathrm{I}-\mathrm{I} .44)]$. There was an air-fluid level on the abdominal X-ray (Fig. I). Abdominal ultrasonography (USG) showed dilatation of small intestine segments and small intestine wall thickening and the presence

Cite this article as: Erdoğan A, Bostanoğlu A. A rarely encountered case: A neuroendocrine tumor in strangulated Littre's hernia. Ulus Travma Acil Cerrahi Derg 2020;26:632-634.

Address for correspondence: Ahmet Erdoğan, M.D.

Kahramanmaraş Elbistan Devlet Hastanesi, Genel Cerrahi Kliniği, Kahramanmaraş, Turkey

Tel: +90 344 - 413800 I E-mail: erdogannumune@hotmail.com

Ulus Travma Acil Cerrahi Derg 2020;26(4):632-634 DOI: 10.14744/tjtes.2019.30378 Submitted: 22.1I.2018 Accepted: 29.07.2019 Online: I5.06.2020

Copyright 2020 Turkish Association of Trauma and Emergency Surgery 


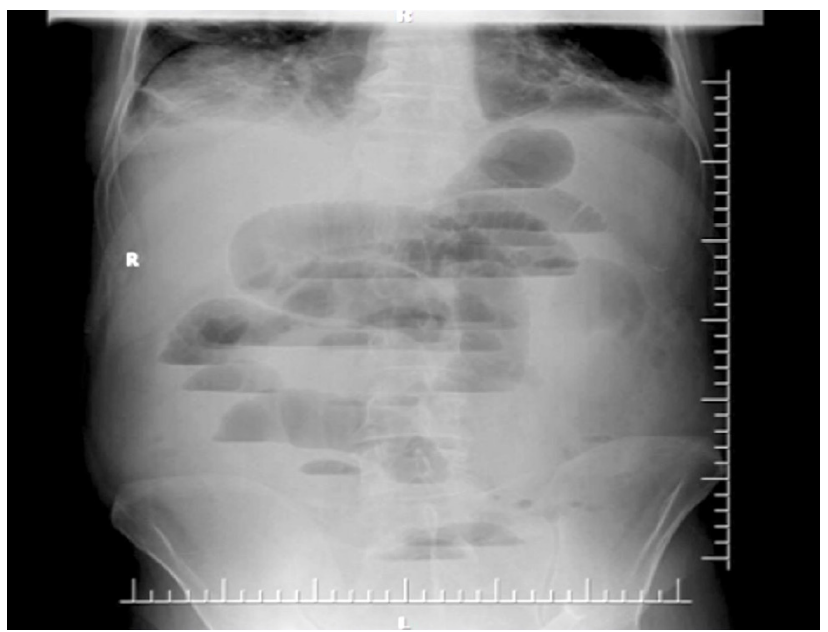

Figure 1. Air-fluid level on the abdominal X-ray.
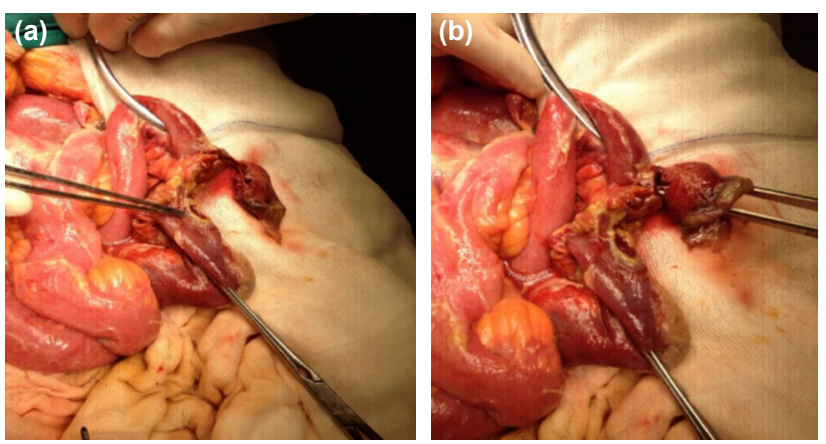

Figure 2. (a, b) Perioperative image of the perforated Meckel's diverticulum.

of fluid between the intestinal loops and the pelvis. Left inguinal USG revealed herniated intestinal loops and fluid in the hernia sac. The patient was operated on with a pre-diagnosis of an acute abdomen due to his herniated intestine. He was operated on under regional anesthesia, as he had pneumonia. There were widespread purulent fluids and intestinal contents in the abdomen. The exploration revealed that the ileum was perforated from the herniated MD into the left internal ring, approximately $120 \mathrm{~cm}$ proximal to the ileocecal valve (Fig. 2a, b). The perforated segment was resected, and a double-barreled ileostomy was performed. The left inguinal canal was narrowed and sutured into the abdomen. The patient was discharged on the 7th postoperative day without any complications. As a result of the patient's pathology, it was reported that there was a well-differentiated NET (WHO 2010, carcinoid/NET GI) with a diameter of $0.3 \mathrm{~cm}$ with mucosal and submucosal localization in MD; the surgical margins were intact and no mitosis was found. As a result of the immunohistochemical analysis, it was reported that widespread positive staining with chromogranin and synaptophysin was present in the tumor cells, and the Ki-67 proliferation index was around $1 \%$. Patient consent was obtained for this study.

\section{DISCUSSION}

Meckel's diverticulum is the true diverticulum that holds the entire layer of the small intestine. It is usually located in 45-90 $\mathrm{cm}$ proximal to the ileocecal valve. In the literature, diverticula of $\mathrm{I}-56 \mathrm{~cm}$ in length and $\mathrm{I}-50 \mathrm{~cm}$ in width have been reported. ${ }^{[4]}$ In this case, MD was located approximately 120 $\mathrm{cm}$ proximal to the ileocecal valve. In the pathology report, the diverticulum length was reported to be $3 \mathrm{~cm}$, and the diameter was $2 \mathrm{~cm}$. MD includes ectopic mucosal areas, especially of the gastric type. Benign lesions, such as lipoma and leiomyoma, or malignant proliferative-type lesions, such as adenocarcinoma, malignant sarcoma, and often carcinoid tumors may develop here. ${ }^{[5]}$ In this case, a NET was observed in MD. Carcinoid tumors in MD are about 2.5 times more common in males than females. The mean age of onset is 55 years. Five-year tumor-specific survival is $100 \%$ in stage $I$ and stage II patients..$^{[6]}$ This patient was male, and his age was 7 I, compatible with the literature. There was no recurrence in the $48^{\text {th }}$ month of follow-up, and the patient is still alive.

MD is usually asymptomatic. MD often occurs with complications. The MD complication rate is approximately $4 \%$, which include bleeding, infection, and obstruction. The most common causes of obstructions are intussusception, volvulus of the diverticulum, and rarely the penetration of the diverticulum into the hernia sac (Littre's hernia). ${ }^{[3]}$ Littre's hernia has been reported in the forms of approximately $50 \%$ inguinal, $20 \%$ femoral, $20 \%$ umbilical, and $10 \%$ other hernias. In this case, Littre's hernia was in the form of a strangulated inguinal hernia. The presence of MD in the incarcerated inguinal hernia sac is only determined perioperatively. It is extremely difficult to preoperatively reveal the presence of MD in the hernia sac. ${ }^{[7]}$ It is also almost impossible to diagnose with USG and computed tomography. Imaging methods can be helpful to observe secondary findings, such as the presence of fluid in the hernia sac and bowel wall thickening. ${ }^{[8]}$ In this case, the presence of MD in the hernia sac was found during the operation. Preoperative USG revealed the presence of bowel loops and fluid in the hernia sac, but MD was not revealed.

Table I. $2010 \mathrm{WHO}$ classification of the neuroendocrine neoplasms

\begin{tabular}{lccc}
\hline & Grade & Mitotic count (10 HPF) & Ki 67 index \\
\hline Well-differentiated neoplasms & NET GI & $<2$ & $\leq 2 \%$ \\
& NET G2 & $2-20$ & $3-20 \%$ \\
Poorly differentiated neoplasms & NEC G3 (large or small-cell) & $>20$ & $>20 \%$ \\
\hline
\end{tabular}

HPF: High-Power Field; NEC: Neuroendocrine Carcinoma; NET: Neuroendocrine Tumor; WHO: World Health Organization. 
In the presence of symptomatic MD and incarcerated Littre's hernia, the treatment is surgery. The treatment is simple diverticulectomy or the resection of the segmentary small intestine that includes the diverticulum and, in the presence of a hernia, herniorrhaphy. The surgical removal of MD is recommended, as it contains ectopic mucosa, and there is a risk of bleeding. ${ }^{[1,2]}$ There is no special algorithm recommended for NETs in MD in NET guidelines. In recent studies, it has been reported that the prognosis of NETs in MD is similar to that of ileal tumors. If the diameter of the tumor in MD is higher than $\mathrm{I} \mathrm{cm}$, segmentary small intestine resection is recommended; however, if the tumor diameter is smaller than I cm, diverticulectomy is reported to be sufficient. ${ }^{[9]}$ In the current guidelines for ileum and jejunum NETs of the European Neuroendocrine Tumor Society (ENETS), resection with intact surgical margins and lymph node dissection through the mesenteric artery is recommended for nonmetastatic NETs. ${ }^{[10]}$ In this case, MD penetrated the hernia sac and was perforated; therefore, a resection, including the diverticulum, was performed. The postoperative pathology revealed that the tumor diameter in $M D$ was $0.3 \mathrm{~cm}$, and the surgical margins were intact. There was no need for a secondary operation. There have been many classifications on neuroendocrine tumors. To provide consensus on this issue, the World Health Organization (WHO) classified the tumors in accordance with the proliferative activity on 2010 (Table I). ${ }^{\left[{ }^{I I}\right]}$ The pathology result of this case revealed a well-differentiated Grade I NET according to the 2010 classification of WHO.

The interesting part of this case is that cases of incarcerated Littre's hernia or NETs in MD have been reported in the literature, but we have not encountered any case of a NET in incarcerated Littre's hernia in our literature review.

In conclusion, patients with suspected strangulation should be operated on immediately. If MD is detected in the hernia sac, we believe that it should be completely resected, as aNET can be observed in the ectopic tissue, even if only rarely.

Informed Consent: Written informed consent was ob- tained from the patient for the publication of the case report and the accompanying images.

Peer-review: Internally peer-reviewed.

Authorship Contributions: Concept: A.E., A.B.; Design: A.E., A.B.; Supervision: A.B.; Fundings: A.E., A.B.; Materials: A.E.; Data: A.E.; Analysis: A.B.; Literature search: A.E.; Writing: A.E.; Critical revision: A.B.

Conflict of Interest: None declared.

Financial Disclosure: The authors declared that this study has received no financial support.

\section{REFERENCES}

1. Skandalakis PN, Zoras O, Skandalakis JE, Mirilas P. Littre hernia: surgical anatomy, embryology, and technique of repair. Am Surg 2006;72:238-43.

2. Horkoff MJ, Smyth NG, Hunter JM. A large incarcerated Meckel's diverticulum in an inguinal hernia. Int J Surg Case Rep 2014;5:899-901.

3. Lequet J, Menahem B, Alves A, Fohlen A, Mulliri A. Meckel's diverticulum in the adult. J Visc Surg 2017;154:253-9. [CrossRef]

4. Malik AA; Shams-ul-Bari, Wani KA, Khaja AR. Meckel's diverticulumRevisited. Saudi J Gastroenterol 2010;16:3-7. [CrossRef]

5. Caracappa D, Gullà N, Lombardo F, Burini G, Castellani E, Boselli C, et al. Incidental finding of carcinoid tumor on Meckel's diverticulum: case report and literature review, should prophylactic resection be recommended? World J Surg Oncol 2014;12:144. [CrossRef]

6. Mora-Guzmán I, Muñoz de Nova JL, Martín-Pérez E. Neuroendocrine tumours within a Meckel's diverticulum. Ann R Coll Surg Engl 2018;100:e10-1. [CrossRef]

7. Mirza MS. Incarcerated Littre's femoral hernia: case report and review of the literature. J Ayub Med Coll Abbottabad 2007;19:60-1.

8. Citgez B, Yetkin G, Uludag M, Karakoc S, Akgun I, Ozsahin H. Littrés hernia, an incarcerated ventral incisional hernia containing a strangulated meckel diverticulum: report of a case. Surg Today 2011;41:576-8.

9. Escarrà JM, Fraccalvieri D, Paules Villar MJ, Kreisler Moreno E. Neuroendocrine tumor in Meckel's diverticulum: An unusual finding. Cir Esp 2015;93:e135-6. [CrossRef]

10. Niederle B, Pape UF, Costa F, Gross D, Kelestimur F, Knigge U, et al; Vienna Consensus Conference participants. ENETS Consensus Guidelines Update for Neuroendocrine Neoplasms of the Jejunum and Ileum. Neuroendocrinology 2016;103:125-38. [CrossRef]

11. Rindi G, Arnold R, Bosman FT. Nomenclature and classification of neuroendocri neoplasms of the digestive system. In: Bosman TF, Carneiro F, Hruban RH, Theise ND, editors. WHO classification of tumours of the digestive system. 4th ed. Lyon: International Agency for Research on cancer (IARC); 2010.p.13.

\section{OLGU SUNUMU - ÖZET}

\section{Nadir görülen bir olgu: Strangüle Littre hernisi içerisinde nöroendokrin tümör Dr. Ahmet Erdoğan, ${ }^{1}$ Dr. Akın Bostanoğlu ${ }^{2}$}

${ }^{1}$ Kahramanmaraş Elbistan Devlet Hastanesi, Genel Cerrahi Kliniği, Kahramanmaraş

${ }^{2}$ Ankara Numune Eğitim ve Araştırma Hastanesi, Genel Cerrahi Kliniği, Ankara

Littre hernisi, fitık kesesi içerisinde, Meckel divertikülünün olduğu nadir bir durumdur. Meckel divertikülü ise ince bağırsağın gerçek divertikülüdür. İçerisinde nöronendokrin tümör gelişebilir, ancak bildirilen olgu sayısı azdır. Bu yazıda, literatür taramasında hiç rastlamadığımız, strangüle Littre hernisi içerisinde nöroendokrin tümörün olduğu bir olgu sunduk. 7I yaşında erkek hasta, sol kasık ağrısı ve kasıkta şişlik şikayeti ile polikliniğimize başvurdu. Aynı zamanda hastanın karın muyanesinde akut karın bulguları mevcuttu. Hasta acil ameliyat edildi, operasyonda herniye olmuş Meckel divertikülünün perfore olduğu izlendi. Segmenter ince bağırsak rezeksiyonu yapıldı. Hastanın patoloji sonucunda; ince bağırsaktaki Meckel divertikülü içerisinde mukoza ve submukoza yerleşimli iyi diferansiye nöroendokrin tümör izlendi. İnkarsere hernilerde, herni kesesi içerisinde Meckel düvertikülü saptanırsa, çok nadir de olsa nöroendokrin tümör görülebileceğinden tamamen rezeke edilmesi gerektiğini düşünmekteyiz.

Anahtar sözcükler: Littre hernisi; Meckel divertikülü; nöroendokrin tümör.

Ulus Travma Acil Cerrahi Derg 2020;26(4):632-634 doi: 10.14744/tjtes.2019.30378 